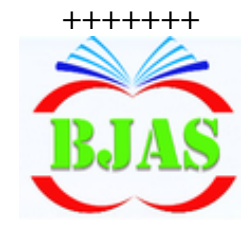

Available online at http://journal.bajas.edu.iq

College of Agriculture, University of Basrah

DOi:10.21276/basjas

ISSN 1814 - 5868 Basrah J. Agric. Sci., 32(Spec Issue): 236-246, 2019

\section{Basrah}

Journal of

Agricultural

Sciences

E-ISSN: 2520-0860

\title{
Determination of Polycyclic Aromatic Hydrocarbons (PAHs) in some Imported Fishes
}

\author{
Marwa K. Abbas ${ }^{1}$, Faroq M.K. Al-Habeeb ${ }^{1} \&$ Abdulkareem T. Yesser $^{2}$ \\ ${ }^{1}$ Department of Food Science, College of Agriculture, University of Tikrit, Iraq \\ ${ }^{2}$ Department of Marine Vertebrates, Marine Science Centre, University of Basrah, \\ Iraq \\ *Corresponding author e-mail: abdulkareemtaher@gmail.com
}

Received 6 June 2019; Accepted 30 August 2019; Available online 10 October 2019

\begin{abstract}
Samples of frozen fish available in Kirkuk markets were Shad Tenualosa ilisha (Hamilton), Mackerel Trachurus trachurus (Linnaeus), Rainbow trout Oncorhynchus mykiss (Walbaum) and striped catfish (Pangasianodon hypophtholmus (Sauvage). They collected for the period $1^{\text {st }}$ May 2015 to $30^{\text {th }}$ January 2016 at weights average between 650-1250 g. The results showed many of carcinogenic and non-carcinogenic hydrocarbons compounds; Rainbow trout contained seven and nine of hydrocarbons compounds in the extracts of hexane and ethanol respectively, among them, there were five carcinogenic hydrocarbons in the ethanol extract and three in the hexane, their values ranged between 0.234-19.707 and 0.419-2.972 $\mathrm{ng}^{-\mathrm{g}^{-1}}$ dry weight respectively. Numbers of the hydrocarbons ranged between 4-6 in other fish species. This may due to the differences of nature of feeding among the fish species and the differences in their fat content. In Shad fish, the results have recorded one carcinogenic compound in the ethanol and five in the hexane, the concentration of Benzo (a) pyrene reached 24.23 ng. $\mathrm{g}^{-1}$ dry weight which is the most dangerous component among carcinogenic compound. Mackerel contains five compounds of hydrocarbons in the hexane; Four of them belong to the non-carcinogenic group and six in ethanol, five of them are non- carcinogenic. This study showed that differences in the numbers and concentrations of aromatic hydrocarbons in the studied fish. This is due to several reasons such as occurrences of fish near to the sources of hydrocarbons pollution. the nature of fish feeding and living.
\end{abstract}

Key words: Aromatic Hydrocarbon, Shad, Mackerel, Striped catfish, Rainbow trout.

\section{Introduction}

Fish is the biggest group among the animal kingdom that is consumed. about 1000 species from 30000 are used as commercial food that is consumed dried, canned, salted or smoked (Sándor et al., 2011). Fish has a nutritional value because of it contains sahigh quality of proteins and is a good source of calcium, iron and phosphorus as well as a vitamin B (Rahimi et al., 2010).

Consuming fish protein is increasing more than other animal protein, this is because fish is characterized by low cholesterol levels (Verbeke et al., 2007). The United States are 
the world's third largest state in consuming of food in the word, and about $20 \%$ of sea food including of their food according to FAO data (Boadi et al., 2011). However, fish food is healthy, it may be more subject to chemical pollutants from its environment, (Hajeb et al., 2009).

Iraq imports large amounts of frozen fish, fillets, fish portion, headless fish products or whole fish from different countries such as India, Bangladesh, Vietnam, Turkey, UAE and Morocco, these fish may be exposed to hydrocarbon pollutants, and by eating fish products that were contaminated with aromatic hydrocarbons and by leads that were poisoning (Bordajandi et al., 2004).

Distribution of petroleum hydrocarbons in commercial fish species in Iraqi coastal area North-West Arabian Gulf and in Shatt AlArab River were studied (Al-Saad et al., 1989; Al-Saad, 1995; Al-Saad et al.,1997; Hantoush et al., 2001; Al-Ali et al., 2016), while Al-Abdul-Nebi et al. (2013), studied

Table (1): Types and concentration of Poly Aromatic Hydrocarbons (PAHs) in the studied fish.

\begin{tabular}{clccc}
\hline $\begin{array}{c}\text { Sample } \\
\text { No. }\end{array}$ & Species & Company & Origin & Remarks \\
\hline 1 & Shad (Tenualosa ilisha) & Tahani & India & $\begin{array}{c}\text { Packed in Iraq } \\
\text { within the validity period }\end{array}$ \\
\hline 2 & $\begin{array}{l}\text { Catfish (Pangasianodon } \\
\text { hypophtholmus) }\end{array}$ & Al- Baraa & Iraq & within the validity period \\
\hline 3 & $\begin{array}{l}\text { Rainbow trout } \\
\text { (Oncorhynchus mykiss) }\end{array}$ & $\begin{array}{c}\text { Kaskin } \\
\text { Oglu }\end{array}$ & Turkey & Within the validity period \\
\hline & Mackerel (Trachurus trachurus) & Americana & Thailand & $\begin{array}{c}\text { Packed in UAE, within the } \\
\text { validity period) }\end{array}$ \\
\hline
\end{tabular}

the aromatic hydrocarbons in muscles of some imported fish (frozen and canned) from local market of Basrah province, southern of Iraq.

The present study aims to identify the levels of hydrocarbons in four species of fish, including, shad, striped cat fish, rainbow trout and mackerel imported through the northern border of Erbil, Duhok and Kirkuk. The Poly Aromatic hydrocarbons (PAHs) were determined as a carcinogenic hydrocarbon.

\section{Materials and Methods}

\section{Samples collection}

Frozen fish from the local markets of the of Kirkuk city were collected from the period, $1^{\text {st }}$ May 2015 until 30 $30^{\text {th }}$ January 2016. Fish samples included four brands representing different origin (Iraq, India, Thailand and Turkey), these included different samples from the most popular fish in the local markets as it is explained in table (1).

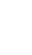


The average weight of fishes were (6501250) grams, the fish were transferred in ice boxes then to the central laboratory of the Directorate of Agriculture and Irrigation, Kirkuk Governorate to prepare the samples. The head, skin and viscera of the fish were removed manually using sharp knives. These parts of body were placed in plastic bags, And freeze.

\section{Fat extraction}

Solvent extraction method was conducted to extract fat from freeze dryer fish tissues according to the method of Al-Saad (1995), two solvents (98\% ethanol) as a polar solvent and $100 \%$ hexane as a non-polar solvent were used. The extracted lipid samples were transferred to the laboratories of the Department of Environmental Chemistry of Marine Science Centre, University of Basrah for the purpose of hydrocarbons measurement. Hydrocarbon separation was performed used gas chromatograph (HPLC, Agilent $6890 \mathrm{~N}$-USA), compared to the standard curve as shown in Fig (1).

\section{Determination of Polycyclic Aromatic Hydrocarbons (PAHs)}

A method of Grimalt \& Olive (1993) was used to extract hydrocarbons. A mixture of standard compounds of polycyclic aromatic compounds was used to determine the concentrations of hydrocarbons compounds in different fish samples.

The blank sample was extracted as mentioned in previous. Concentrations were estimated using the equation described in APHA (2005).

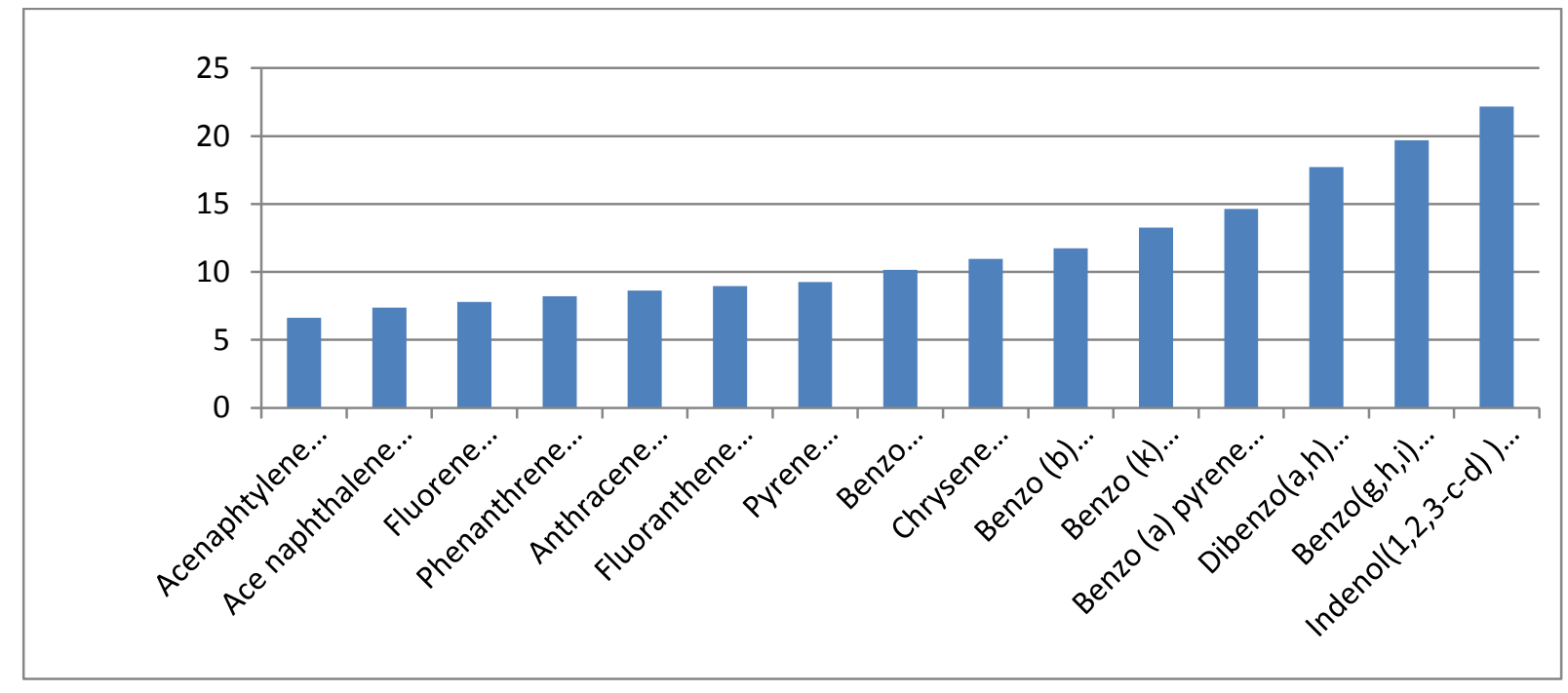

Fig. (1): The standard curve of Aromatic hydrocarbons.

\section{Results \& Discussion}

Polycyclic Aromatic Hydrocarbons (PAHs)

The results exhibited in table (2). That indicated the present many Polycyclic Aromatic Hydrocarbons (PAHs)compounds, Rainbow trout fish contained 7 and 9 hydrocarbon compounds in the hexane and ethanol extracts, respectively, including five carcinogenic but within the allowable limits, ranged between $0.234-19.707$ ng.g ${ }^{-1}$ for chrysene and Benzo $\{\mathrm{k}\}$ fluoranthene, respectively, while other fish species contains 4 to 8 aromatic hydrocarbon compounds in their tissue. This may be due to the Differences of food in the nature, and the difference in the level of fat contents. Shad 
and Rainbow trout classified as fatty fish that contain more than $9 \%$ fat. Mackerel fish was classified as medium fatty fish more than $3 \%$ fat, while striped catfish was classified as lean fish, which content less than 3\% fat (Hindi et al., 2001).

Haritash \& Kaushik (2009) indicated that hydrocarbons are low water solubility compounds, their solubility increases in water by increasing their molecular weight (Blahova et al., 2010).

The highest compound was Anthracene hydrocarbon compound, with average of $84.196 \mathrm{ng} . \mathrm{g}^{-1}$ in the ethanol extract of Mackerel and acenaphthylene compound in the hexane extract at average $185.1{\mathrm{ng} . \mathrm{g}^{-1}}^{\text {in }}$ Rainbow trout fish.

The hexane extracts indicated that there were five carcinogenic hydrocarbons out of eight compounds recorded the highest values, all of them were found in Shad fish: benzo \{a\} anthracene (0.915) ng.g ${ }^{-1}$, Benzo $\{b\}$ fluoranthene (4.201) ng.g $\mathrm{g}^{-1}$, Benzo $\{\mathrm{k}\}$ fluoranthene (3.348), Dibenzo $\{\mathrm{a}, \mathrm{h}\}$ anthracene (9.3 ng. $\left.\mathrm{g}^{-1}\right)$ and Benzo\{a\}pyrene (24.230 ng. $\left.\mathrm{g}^{-1}\right)$, which is the most dangerous carcinogenic compounds .They exceed the limits that allowed by the European Commission, That recommending not to increase more than $5 \mathrm{ng} . \mathrm{g}^{-1}$.

Table (2): Types and concentration of Polycyclic Aromatic Hydrocarbons (PAHs) in the studied fish.

\begin{tabular}{lcccccccc}
\hline \multirow{2}{*}{ Aromatic Hydrocarbon } & Shad & Shad & $\begin{array}{c}\text { Striped } \\
\text { cat fish }\end{array}$ & $\begin{array}{c}\text { Striped } \\
\text { cat fish }\end{array}$ & $\begin{array}{c}\text { Rainbow } \\
\text { trout }\end{array}$ & $\begin{array}{c}\text { Rainbow } \\
\text { trout }\end{array}$ & Mackerel Mackerel \\
\cline { 2 - 9 } & Hexane & Ethanol & Hexane & Ethanol & Hexane & Ethanol & Hexane & Ethanol \\
\hline Naphthalene & 0 & 0 & 0.427 & 0 & 0 & 0 & 0 & 0 \\
\hline Acenaphthylene & 0 & 0 & 37.246 & 0 & 185.1 & 0 & 12.509 & 0 \\
\hline Acenaphthalene & 4.452 & 1.519 & 3.453 & 76.559 & 156.213 & 6.45 & 0 & 0.391 \\
\hline Fluorene & 0 & 1.883 & 11.176 & 60.009 & 0 & 0 & 32.332 & 11.720 \\
\hline Phenanthrene & 2.667 & 0.496 & 0.814 & 0 & 0 & 0.648 & 2.188 & 2.294 \\
\hline Anthracene & 0 & 14.262 & 34.097 & 0 & 57.593 & 0 & 28.11 & 84.196 \\
\hline Fluoranthene & 0 & 0 & 0.498 & 0 & 0 & 0.599 & 0 & 5.711 \\
\hline Pyrene & 6.280 & 0 & 0 & 0 & 5.478 & 0.205 & 0 & 0 \\
\hline Benzo\{a\}anthracene & 0.915 & 0 & 0 & 0 & 0 & 0.664 & 0 & 0 \\
\hline Chrysene & 0 & 0 & 0 & 0 & 1.592 & 0.234 & 0 & 0.778 \\
\hline Benzo\{b\}fluoranthene & 4.201 & 0 & 0 & 0 & 0.419 & 0.543 & 2.782 & 0 \\
\hline Benzo\{k\}fluoranthene & 3.348 & 0 & 0 & 0.070 & 0 & 19.707 & 0 & 0 \\
\hline Benzo\{a\}pyrene & 24.230 & 0 & 0 & 3.836 & 2.972 & 0 & 0 & 0 \\
\hline Dibenzo\{a,h\}anthracene & 9.300 & 0 & 0 & 0 & 0 & 0 & 0 & 0 \\
\hline Benzo\{g,h,i\}pyrene & 0 & 0 & 4.063 & 0.562 & 0 & 0.579 & 0 & 0 \\
\hline Indenol \{1,2,3-c, d\} pyrene & 0 & 7.610 & 0 & 0 & 0 & 0 & 0 & 0 \\
\hline $\mathbf{1 6 ~ P A H s ~}$ & & 25.770 & 91.774 & 141.036 & 418.367 & 29.629 & 77.921 & 105.090 \\
\hline
\end{tabular}




\section{Polycyclic Aromatic Hydrocarbons (PAHs)in the Shad fish:}

Table (3) revealed the Polycyclic Aromatic Hydrocarbons compounds (PAHs) in the muscles of Shad fish, eight hydrocarbons compounds totally55.393, in the hexane extract, and five Aromatic hydrocarbons compounds in the ethanol extract, as total 25.77. These results were less than those obtained by Alomirah et al. (2009), which was $68.7 \mathrm{ng} \cdot \mathrm{g}^{-1}$. The high contents of total hydrocarbons In current study, may due to the nature of the feeding habit of Shad fish and its biology as they are migratory fish inhabiting the seas then migrates to the estuaries of the rivers in summer, in this migration fish has been exposed to various sources of hydrocarbon contaminants in seas, oceans and rivers.

It is also noted from the table (3) that the average concentration of low carcinogenic aromatic hydrocarbons reached $4.466{\mathrm{ng} . \mathrm{g}^{-1}}^{-1}$ in the hexane extract. This result is consisted with Lobet et al. (2006). The average concentration of low carcinogenic aromatic hydrocarbons in the ethanol extract reached $4.54 \mathrm{ng} \cdot \mathrm{g}^{-1}$. This finding was consistent with Lobet et al. (2006).

Table (3) Types and concentration of Polycyclic Aromatic Hydrocarbons (PAHs) in Shad fish.

\begin{tabular}{|c|c|c|}
\hline \multicolumn{3}{|c|}{ Low carcinogenic aromatic hydrocarbons } \\
\hline PAH Compounds & Shad (Ethanol) & Shad (Hexane) \\
\hline Acenaphthalene & 1.519 & 4.452 \\
\hline Fluorene & 1.883 & 0 \\
\hline Phenanthrene & 0.496 & 2.667 \\
\hline Anthracene & 14.262 & 0 \\
\hline Fluoranthene & 0 & 0 \\
\hline Pyrene & 0 & 6.280 \\
\hline Total & 18.160 & 13.399 \\
\hline Mean & 4.540 & 4.466 \\
\hline \multicolumn{3}{|c|}{ Carcinogenic Aromatic hydrocarbons } \\
\hline PAH Compounds & Shad (Ethanol) & Shad (Hexane) \\
\hline Benzo $\{a\}$ anthracene & 0 & 0.915 \\
\hline Chrysene & 0 & 0 \\
\hline Benzo $\{b\}$ fluoranthene & 0 & 4.201 \\
\hline Benzo $\{k\}$ fluoranthene & 0 & 3.348 \\
\hline Benzo $\{a\}$ pyrene & 0 & 24.23 \\
\hline Dibenzo $\{a, h\}$ pyrene & 0 & 9.300 \\
\hline Benzo $\{\mathrm{g}, \mathrm{h}, \mathrm{i}\}$ pyrene & 0 & 0 \\
\hline Indenol $\{1,2,3-\mathrm{c}, \mathrm{d}\}$ & 7.610 & 0 \\
\hline Total & 7.610 & 41.994 \\
\hline Mean & 7.610 & 8.300 \\
\hline 16 PAHs & 25.770 & 55.393 \\
\hline
\end{tabular}


Abbas et al. / Basrah J. Agric. Sci., 32 (Special Issue): 236-246, 2019

The average concentration of these compounds in sardine was $5.3 \mathrm{ng} . \mathrm{g}^{-1}$. For carcinogenic hydrocarbons, Benzo $\{a\}$ pyrene was higher than the other in the hexane extract.

\section{Polycyclic Aromatic Hydrocarbons (PAHs)in the striped cat fish}

Table (4) exhibited the concentration of total hydrocarbons in striped cat fish $141.038 \mathrm{ng} . \mathrm{g}^{-}$
${ }^{1}$, totally in ethanol extract, and $91.774 \mathrm{ng} \cdot \mathrm{g}^{-1}$ in the hexane extract, the total noncarcinogenic compounds were higher than carcinogenic in both extracted solvents. The values of Benzo $\{\mathrm{a}\}$ pyrene was $3.836 \mathrm{ng} . \mathrm{g}^{-1}$ and is close to the permissible limits of the European Commission 2 ng. $\mathrm{g}^{-1}$. The average concentration of total aromatic hydrocarbons

Table (4): Types and concentration of Polycyclic Aromatic Hydrocarbons (PAHs)in the striped cat fish.

\begin{tabular}{|c|c|c|}
\hline \multicolumn{3}{|c|}{ Low carcinogenic aromatic hydrocarbons } \\
\hline PAH Compounds & striped cat (Ethanol) & striped cat (Hexane) \\
\hline Naphthalene & 0 & 0.427 \\
\hline Acenaphthylene & 0 & 37.246 \\
\hline Acenaphthalene & 76.559 & 3.453 \\
\hline Fluorene & 60.009 & 11.176 \\
\hline Phenanthrene & 0 & 0.814 \\
\hline Anthracene & 0 & 34.097 \\
\hline Fluoranthene & 0 & 0.498 \\
\hline Pyrene & 0 & 0 \\
\hline Total & 136.568 & 87.711 \\
\hline Mean & 68.284 & 12.530 \\
\hline \multicolumn{3}{|c|}{ Carcinogenic Aromatic hydrocarbons } \\
\hline PAH Compounds & striped cat (Ethanol) & striped cat (Hexane) \\
\hline Benzo $\{a\}$ anthracene & 0 & 0 \\
\hline Chrysene & 0 & 0 \\
\hline Benzo $\{b\}$ fluoranthene & 0 & 0 \\
\hline Benzo $\{k\}$ fluoranthene & 0.070 & 0 \\
\hline Benzo $\{a\}$ pyrene & 3.836 & 0 \\
\hline Dibenzo $\{a, h\}$ pyrene & 0 & 0 \\
\hline Benzo $\{\mathrm{g}, \mathrm{h}, \mathrm{i}\}$ pyrene & 0.562 & 4.063 \\
\hline Indenol $\{1,2,3-\mathrm{c}, \mathrm{d}\}$ & 0 & 0 \\
\hline Total & 4.468 & 4.063 \\
\hline Mean & 1.489 & 4.063 \\
\hline 16 PAHs & 141.036 & 91.774 \\
\hline
\end{tabular}




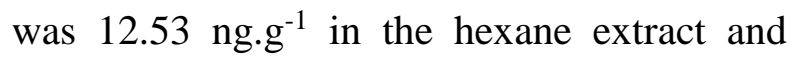
approximated this value has converged with results this result with the study of Al-Saleh \& Al-Doush, (2002), The concentration of total aromatic hydrocarbons in Emperor Lethrinum

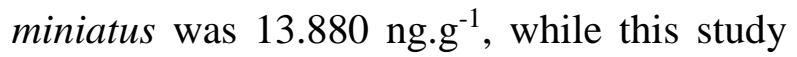
recorded different average concentration of total aromatic hydrocarbons in the ethanol extract. It reached 28.20. $\mathrm{ng}^{-\mathrm{g}^{-1}}$.

In Table (4), the acenaphthene extract with ethanol was higher than for the other carcinogenic compounds. It was also found that Benzo (g, h, i) perylene, extracted by hexane, was higher than for the other carcinogenic compounds, while the benzo-a pyrene extract with ethanol was higher than Benzo $\{\mathrm{g}, \mathrm{h}, \mathrm{i}\}$ pyrene.

\section{Polycyclic Aromatic Hydrocarbons (PAHs)in Rainbow trout:}

Table (5) explained that the total number of polycyclic aromatic hydrocarbons compound in the ethanol extract was nine, five were carcinogenic hydrocarbons and four belonged to the non-carcinogenic hydrocarbons group, Seven types of hydrocarbons appeared in the hexane extract, three carcinogenic hydrocarbons group and four to noncarcinogenic hydrocarbons, The Benzo $\{a\}$ pyrene was approximately 2.972 with the limits allowed by the European Commission, which recommends that the permissible limits of $2 \mathrm{ng} \cdot \mathrm{g}^{-1}$, This may be due to the fact that Rainbow trout fish are migratory fish between the oceans and estuaries that may be exposed during their migration to various oil pollution factors. It is also noted from the table that the average concentration of aromatic hydrocarbons in the hexane extract has reached $59.76 \mathrm{ng} \cdot \mathrm{g}^{-1}$. This result not consisted with that obtained by Webster et al. (2012) in their study of hydrocarbon estimation in fish. The average concentration of aromatic hydrocarbons in the ethanol extract was 3.292 ng. $\mathrm{g}^{-1}$ with Lobet et al. (2006). The total concentration of these compounds in sardines was $5.3 \mathrm{ng} \cdot \mathrm{g}^{-1}$.

Table (5) revealed the Acenaphthylene compound in the hexane extract greater than for the other benzo-k\} fluoranthen compounds in the ethanol extract, which is higher than for the other carcinogenic compounds.

\section{Polycyclic Aromatic Hydrocarbons (PAHs)in mackerel fish}

Table (6) showed that the total number of polycyclic aromatic hydrocarbons compound in the hexane extract was five, one of them were carcinogenic, which is Benzo $\{b\}$ fluoranthene, reaching $2.782 \mathrm{ng} . \mathrm{g}^{-1}$ and four belonged to the non-carcinogenic hydrocarbons group. Six types of aromatic hydrocarbons were recorded in the ethanol extract, one of which belonged to the carcinogenic hydrocarbons group and five to non-carcinogenic hydrocarbon. Chrysene which is the only carcinogenic aromatic hydrocarbon in ethanol extract reaching 0.778 ng. $\mathrm{g}^{-1}$. It is also noted from the table that the average concentration of aromatic hydrocarbons in the hexane extract has

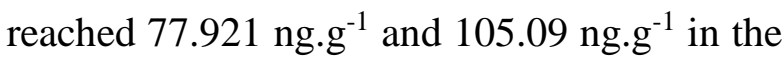
ethanol extract. This result is different compared with that obtained by Webster $e t$ al. (2012) in their study of hydrocarbon estimated in marine fish of Scotland which was $5.6 \mathrm{ng} . \mathrm{g}^{-1}$. The table also showed that the Anthracene which belong to non-carcinogenic group in the ethanol extract was higher than the other non-carcinogenic compounds. 
Abbas et al. / Basrah J. Agric. Sci., 32 (Special Issue): 236-246, 2019

Table (5): Types and concentration of Polycyclic Aromatic Hydrocarbons (PAHs) in Rainbow trout fish.

\begin{tabular}{|c|c|c|}
\hline \multicolumn{3}{|c|}{ Low carcinogenic aromatic hydrocarbons } \\
\hline PAH Compounds & $\begin{array}{c}\text { Rainbow trout } \\
\text { (Ethanol) }\end{array}$ & $\begin{array}{c}\text { Rainbow trout } \\
\text { (Hexane) }\end{array}$ \\
\hline Naphthalene & 0 & 0 \\
\hline Acenaphthylene & 0 & 185.100 \\
\hline Acenaphthalene & 6.450 & 156.213 \\
\hline Fluorene & 0 & 0 \\
\hline Phenanthrene & 0.648 & 0 \\
\hline Anthracene & 0 & 57.593 \\
\hline Fluoranthene & 0.599 & 0 \\
\hline Pyrene & 0.205 & 5.478 \\
\hline Total & 7.902 & 404.384 \\
\hline Mean & 1.975 & 101.096 \\
\hline \multicolumn{3}{|c|}{ Carcinogenic Aromatic hydrocarbons } \\
\hline PAH Compounds & $\begin{array}{l}\text { Rainbow trout } \\
\text { (Ethanol) }\end{array}$ & $\begin{array}{c}\text { Rainbow trout } \\
\text { (Hexane) }\end{array}$ \\
\hline Benzo $\{a\}$ anthracene & 0.664 & 0 \\
\hline Chrysene & 0.234 & 1.592 \\
\hline Benzo $\{b\}$ fluoranthene & 0.543 & 0.419 \\
\hline Benzo $\{k\}$ fluoranthene & $19.707 \mathrm{a}$ & 0 \\
\hline Benzo $\{a\}$ pyrene & 0 & 2.972 \\
\hline Dibenzo $\{a, h\}$ pyrene & 0 & 0 \\
\hline Benzo $\{\mathrm{g}, \mathrm{h}, \mathrm{i}\}$ pyrene & 0.579 & 0 \\
\hline Indenol $\{1,2,3-\mathrm{c}, \mathrm{d}\}$ & 0 & 0 \\
\hline Total & 21.727 & 9.966 \\
\hline Mean & 4.345 & 3.322 \\
\hline 16 PAHs & 29.629 & 418.367 \\
\hline
\end{tabular}


Abbas et al. / Basrah J. Agric. Sci., 32 (Special Issue): 236-246, 2019

Table (6): Types and concentration of Polycyclic Aromatic Hydrocarbons (PAHs) in the Mackerel fish.

\begin{tabular}{|c|c|c|}
\hline \multicolumn{3}{|c|}{ Low carcinogenic aromatic hydrocarbons } \\
\hline PAH Compounds & Mackerel (Ethanol) & Mackerel (Hexane) \\
\hline Naphthalene & 0 & 0 \\
\hline Acenaphthylene & 0 & 12.509 \\
\hline Acenaphthalene & 0.391 & 0 \\
\hline Fluorene & 11.720 & 32.332 \\
\hline Phenanthrene & 2.294 & 2.188 \\
\hline Anthracene & $84.196 \mathrm{a}$ & 28.110 \\
\hline Fluoranthene & 5.711 & 0 \\
\hline Pyrene & 0 & 0 \\
\hline Total & 104.312 & 75.139 \\
\hline Mean & 20.862 & 18.784 \\
\hline \multicolumn{3}{|c|}{ Carcinogenic Aromatic hydrocarbons } \\
\hline PAH Compounds & Mackerel (Ethanol) & Mackerel (Hexane) \\
\hline Benzo $\{a\}$ anthracene & 0 & 0 \\
\hline Chrysene & $0.778 \mathrm{a}$ & 0 \\
\hline Benzo $\{b\}$ fluoranthene & 0 & 2.782 \\
\hline Benzo $\{k\}$ fluoranthene & 0 & 0 \\
\hline Benzo $\{a\}$ pyrene & 0 & 0 \\
\hline Dibenzo $\{a, h\}$ pyrene & 0 & 0 \\
\hline Benzo $\{\mathrm{g}, \mathrm{h}, \mathrm{i}\}$ pyrene & 0 & 0 \\
\hline Indenol $\{1,2,3-\mathrm{c}, \mathrm{d}\}$ pyrene & 0 & 0 \\
\hline Total & 0.778 & 2.782 \\
\hline Mean & 0.778 & 2.782 \\
\hline 16 PAHs & 105.09 & 77.921 \\
\hline
\end{tabular}

\section{Conclusions}

It conducted that, contamination of fishes by hydrocarbons was clearly obvious, (PAHs, containing 5 compounds in the shad fish and striped cat fish (in the ether extract). Nine compounds in Rainbow trout fish (in the hexane extract), while the number of PAHs in the hexane extract was 5 in mackerel and 8 in shad and striped cat fish. The number of carcinogens compounds in the ether extract ranged from 1 in shad and mackerel and 5 in trout. In the hexane extract, the number of carcinogens compound was 1 in striped cat fish and mackerel and 5 in shad. The highest value of the PAHs content was in Rainbow trout $418.367 \mathrm{ng}^{-1} \mathrm{~g}^{-1}$ in the ether extract and 
$141.038 \mathrm{ng}^{-\mathrm{g}^{-1}}$ in the striped cat fish (hexane extract).

\section{Acknowledgements}

The authors extend their thanks and appreciation to the Directorate of Agriculture of Kirkuk for the facilities provided by its members in the preparation of samples for analysis, as well as thanks to the Department of Marine Chemistry at the Marine Science Centre, University of Basrah in the measurement of PAHs.

\section{References}

Al-Abdul-Nebi, S.A.S.; Yesser, A.K.T. \& AlTaee, M.A.J. (2013). Extraction and estimation of some polynuclear aromatic hydrocarbons in muscles of imported frozen and canned fish species. Basrah J. Agric. Sci., 26(Spec. Issue 2): 98-113.

Alomirah, H.; Al-Zenki, S.; Husain, A.; Ahmed, N.; Al-Rashdan, A.; Gevao, B. \& Sawaya, W. (2009). Dietary exposure to polycyclic aromatic hydrocarbons from commercially important seafood of the Arabian Gulf. J. Food Agric. Environ., 7(1): 9-15.

Al-Saad, H.T. (1995). Distribution and source of hydrocarbons in Shatt AlArab Estuary and North-West Arabian Gulf. Ph. D. Thesis, Coll. Sci., Univ. Basrah: 186pp.

Al-Saad, H.T. \& Al-Asadi, M.K. (1989). Petroleum hydrocarbon concentrations in fishes from Shatt AL-Arab river. Mar. Mesopot., 4(2): 233-242.

Al-Saad, H.T.; Shamshoom, S.M. \& Abaychi, J.K. (1997). Hydrocarbons in fishes from Shatt Al-Arab and N.W. Arabian Gulf Oil spill of 1991. Mar. Mesopot., 12(2): 213-231.
Al-Saleh, I. \& Al-Doush, I. (2002). Gas chromatography-mass spectrometric determination of polycyclic aromatic hydrocarbons in five species of fish from three sites in the Arabian Gulf. Int. J. Environ. Heal. Res., 12: 193200.

APHA (2005) Standard Methods for the Examination of Water and Wastewater. $21^{\text {st }}$. ed., American Public Health Association/American Water Works Association/Water Environment Federation, Washington D.C. :541pp

Al-Ali, B.; Al-Bidhani, M.F.; Al-Khion, D.D.; Al-Nagar, G.A.; Al-Saad. H.T.; Khwadem, A.A.; Zeidan, A.M.; Mahdi, S. \& Hantoush, A.A. (2016). Environmental Assessment of Petroleum Hydrocarbons in fish species from North-West Arabian Gulf. J. Pharm. Chem. Biol. Sci., 4(2): 126-134.

Blahova, J.; Kruzikova, K.; Kasiková, B.; Stierand, P.; Jurcikova, J.; Ocelka, T. and Svobodova, Z. (2010). 1Hydroxypyrene-A Biochemical marker for $\mathrm{PAH}$ pollution assessment of aquatic ecosystem, Sensors, 10: 203-217.

Bligh, E.G. \& Dyer, W.J. (1959). A rapid method of total lipid extraction and purification. Can. J. Biochem. Physiol., 37(8): 911-917.

Boadi, N.O.; Twumasi, S.K.; Badu, M. \& Osei, I. (2011). Heavy metal contamination in canned fish marketed in Ghana. AJSIR, 2(6): 877-882.

Bordajandi, L.R.; Gomez, G.; Abad, E.; Rivera, J.; del Mar Fernandez-Baston, M.D.M.; Blasco, J. \& Gonzalez, M.J. 
(2004). Survey of persistent organochlorine contaminants (PCBs, $\mathrm{PCDD} / \mathrm{Fs}$, and PAHs), heavy metals $(\mathrm{Cu}, \mathrm{Cd}, \mathrm{Zn}, \mathrm{Pb}$, and $\mathrm{Hg})$, and arsenic in food samples from Huelva Spain: levels and health implications. J Agric. Food Chem., 52: 992-1001.

Grimalt, J.O. \& Olive, J. (1993). Source input elucidation in aquatic systems by factor and principal component analysis of molecular marker data. Anal. Chim. Acta, 278:159-176. DOI:10.1016/0003-2670(93)80094-2.

Hajeb, P.; Jinap, S.; Ismail, A.; Fatimah, A.B.; Jamilah, B \& Abdul Rahim, M. (2009). Assessment of mercury level in commonly consumed marine fishes in Malaysia, Food Control, 20: 79-84.

Hindi, M.J.; Sharifi, H.R. \& Shatti, S.M. (2001). Specific criteria for fresh carp and Shad fish. Change of chemical directories. during ice storage $\left(4^{\circ} \mathrm{c}\right)$. J. Arab Agric. Res., 5(1): 177-169.

Hantoush, A.A.; Al-Imarah F.J. \& Abdullah S.B. (2001). Seasonal variation of petroleum hydrocarbon concentration in fish water and marine fishes from Shatt Al-Arab river and N.W. Arabian Gulf. Mar. Mesopot., 16(2): 441-451.

Haritash, A.K. \& Kaushik C.P. (2009). Biodegradation aspects of polycyclic aromatic hydrocarbons (PAHs): A review. J. Hazard Mater., 169: 1-15.
Lobet, J.M.; Falco, G.; Bocio, A. \& Domingo, J.L. (2006). Exposure to polycyclic aromatic hydrocarbons through consumption of edible marine species in Catalonia, Spain. J. Food Protec., 69(10): 2493-2499.

Rahimi, E.; Hajisalehi, M.; Kazemeini, H.R.; Chakeri, A.; Khodabakhsh, A.; Derakhshesh, M.; Mirdamadi, M.; Ebadi, A.G.; Rezvani, S.A, \& Kashkahi, M.F. (2010). Analysis and determination of mercury, cadmium and lead in canned tuna fish marketed in Iran. Afr. J. Biotechnol., 9(31): 4938-4941.

Sándor, Z.; Gy. Papp, Z. ; Csengeri, I. \& Jeney, Z. (2011). Fish meat quality and safety. Tehnol. Mesa, 52(1): 97105.

Verbeke, W.; Sioen, I.; Brunsø, K.; De Henauw, S. \& Camp, J.V. (2007). Consumer perception versus scientific evidence of farmed and wild fish: exploratory insights from Belgium. Aquacult. Int., 15: 121-136.

Webster, L.; Russell, M.; Hussy, I.; Packer, G.; Dalgarno, E.J.; Craig, A.; Moore, D.C.; Jaspars, M. \& Moffat, C.F. (2012). Environmental assessment of the Elgin gas field incident. Report 5, fish and sediment update, Marine Scotland Sci. Rep. 17/12: 113. 